Adrijana Vuković1,

Goran Đoković2,

Aleksandra Pavićević

Fakultet za trgovinu i bankarstvo, Alfa univerzitet,

Beograd
SCIENTIFIC REVIEW ARTICLE doi:10.5937/ekonomika1504155V

Received: October 29, 2015

Accepted: December 3, 2015

\title{
GIOBAL TRENDS IN TRADE WITH REFERENCE TO REPUBLIC OF SERBIA
}

\begin{abstract}
Abstrakt
Powerful and dynamic changes are present in all spheres of society, both at national and at the global level. Those changes are very difficult to monitor due to intensive frequency of change. The changes are also present in trade. This work analyzed changes that are coming from the global environment, that intensely affect the development of modern trade. The question is whether modern trade can handle strikes coming from the global development.

Large industries, commercial and financial organizations and national economies increasingly connect and turn into mutually conditional and interdependent. Greater trade integration is evident, in every year increased trade results in a higher share of exports and imports in GDP.

This work also emphasizes on business performances of trade in Serbia. Results of research show that business performances of trade are still weak, though recently improved marginally. Developments in the field of trade and the change of perception of trade itself drastically improved. Despite of some improvements of business performances, modern trading and market structure relatively slowly develops and it is certain that Serbian trade still largely lagging behind comparing the trade of the European Union.
\end{abstract}

Key words: modern trade, global trends, economic policy, changes, development

JEL classification: R11, R13

\section{ГЛОБАЛНА КРЕТАҢА У ТРГОВИНИ СА ОСВРТОМ НА СРБИЈУ}

\begin{abstract}
Апстракт
Снажне и динамичне промене присутне су у свим сферама развоја друштва, како на националном, тако и на глобалном плану. Учесталост промена је таквог интезитета да их је веома тешко пратити. Те промене су присутне и у трговини. Промене које долазе из глобалног окружења,
\end{abstract}

\footnotetext{
1 adrijana.vukovic@alfa.edu.rs

2 goran.djokovic@alfa.edu.rs

3 aleksandra.pavicevic@alfa.edu.rs 
интезивно утичу на развој савремене трговине. Поставља се питање, да ли савремена трговина може поднети ударе које доносе глобална кретана.

Све више се повезују, узајамно условљавају и доводе у све већу међузависност велике индустрије, трговачке и финансијске организације, националне привреде. Већа трговинска повезаност је евидентна, јер је готово сваке године присутан пораст трговине, ито се резултује све већим учешћем извоза и увоза у друштвеном производу.

Пословне перформансе трговине у Србији су још увек слабе, иако су у последње време незнатно побољшане. Кретања у сфери трговине и сама промена периепиије о трговини, су драстично напредовала. Али, и поред извесних побољшања пословних перформанси, релативно се споро изграђује модерна трговина и структура тржишта, и сигурно је да трговина Србије још увек, у великој мери заостаје у односу на трговину Европске уније.

Кьучне речи: савремена трговина, глобална кретања, економска политика, промене, развој

\section{Introduction}

Economic reality and processes occurring in recent years in the world economy, confirm that economic relations and development processes are increasingly subject of globalization. Connectivity and interdependence of industrial, commercial and financial organizations, as well as the national economy is growing. The basic parameters of contemporary changes in the world do not refer only to political dependency, but also to economic dependence and informational globalization as well. (Leković, 1999, p.127).

The transformation of the world economy into economy of the world is becoming more intensive and brings a qualitative change in economic relations and flows of the world economy. The global system of doing business and creating a dynamic and flexible economic world order are products of intensive globalization process. This is especially evident in the strategy of leading companies - the transnational corporations and national economies.

Globalization is manifested in different forms, but its presence most intensively effects on: trans-nationalization of production and trade, the computerization of society at the global level, new forms of regional cooperation, increased number and spread of activities of international organizations, the availability of scientific information and equalizing conditions of operation and cooperation.

\section{The structural changes in contemporary trade}

From the standpoint of the world economy and trade, the end of XX and beginning of XXI century is characterized by large fluctuations and structural changes and realignments between countries. Changes in modern trade directly caused establishment of new relationships between key stakeholders. The globalization and internationalization of trade and strong international competition, generates permanent changes (Vukmirica, 2000, p. 67). 
The changes coming from the global environment intensely affect the development of modern trade. The changes of such intensity are radically transforming the traditional concept of trade. Trade is increasingly affected by the processes of concentration. The integration of world economies into regional trade and integration blocks further contributes to the complexity of the functioning of the entire world market (Lovreta, 1999, p. 7).

One of the most important features of the new global economy and the modern trade is the growing connection between highly developed and developing countries. There has been an increasing in openness of national economies. The poor nations of the world have become part of the global trading system, finance and manufacturing. For supporters of globalization, this development promises greater gains from trade and faster growth for both parts of the world divided by the level of income. For the skeptics, integration of rich and poor promises increasing in equality of the rich and greater dislocation of the poor.

There has been a shift in balance of power in the economy of developed market economies, namely in the direction of the dominant role of large retail companies. The modern world is evolving towards a single economic process, where transnational corporations appear as well as their subsidiaries. They see the world now as one big market place (Vuković, et al., 2013).

Among them, a strong competition is taking place. They want to fully internationalize its businesses and expand into markets in which they had not previously operated.

National markets are becoming tight for big companies. Antimonopoly regulation limits them, and therefore the big companies are finding modalities for expansion into new markets. Most trading activities are in the hands of a small number of large retailers. In Europe, the top ten companies achieved most of the turnover in the trade, and in some countries, even the top five. Large companies integrate small companies into their systems or expel them from the market. In the countries of transition economies a local merchants disappear. Statistics of the trade sector show that in many western countries, ten major companies are producing about $80 \%$ of turnover, and the first five about $60 \%$ of turnover (Eurostat, 2015, www.epp.eurostat.ec.europa.eu).

The speed and nature of changes occurring in the trade could freely be marked as a real trade revolution. Trade has experienced real expansion using modern information technologies, which led to the complete adaptation of trade to demands and needs of consumers (Župljanin, 2010, p. 119).

Electronic commerce as one of the most important characteristics of modern commerce, allows the efficient functioning of global organizations worldwide. Transnational companies with many branches, developed network of suppliers, distributors, banks, customers, constitute an extremely complex system. A successful functioning of that system is ensured through informational and electronic technology support. In this sense, world trade is increasingly shifted to telecommunication devices. Electronic commerce provides fast, efficient, continuous and complex performance of all business operations related to trade (Radosavljević, 2006, p.47.) 


\section{Global trends in the world and their impact on trade}

The dynamic development of world's economy has caused major changes in its very structure, its relationship with national economies, changes in trade, as well as the differences between successful and unsuccessful trade policy (Leković, 1999, p.128).

Economic trends in the international environment have deteriorated in recent years due to the reduction in global demand and increasing geopolitical tensions. The economies of most countries globally are faced with constraints and structural problems that are slowing down economic growth. The biggest challenge of the economy today, is to create conditions for job creation. Changes in financial markets influence on economic developments in the world as well as uncertainty in the businesses which deepens the fragility of the world's banking system. At the global level economic imbalances are widening, and recently overcome recession is threatened by indebting, deepening employment crisis, announcing the demographic threat of poverty as a result of the widening gap of rich and poor, famines, new migrations. Uncertainties and risks effecting economic trends are numerous and different, because the most urgent problems have not been solved, and may diametrically change the planned projection of the global economy.

However, studies indicate a recovery of the world economy, so that developed economies expect gradual growth. Global indicators confirm the enhanced growth in the short term and the longer-term perspective, as well as strengthening of global economic activity. Monetary policy in developed countries continues to encourage the financial markets and the recovery of the world economy.

In 2015, according to forecasts of the International Monetary Fund, the expected recovery and growth of the global economy is $3.8 \%$, compared with last year's $3.3 \%$, and it is estimated that the global growth would be led by China and the US, while Euro Zone will again negatively impact on the world economy with minimal growth of $0.8 \%$. China's economy in 2015 would slow down the growth from last year's $7.3 \%$ to $7.1 \%$, and would turn to greater internal consumption, to the detriment of investment. The United States in 2015 will have the highest growth in the past decade of $3.1 \%$. Acceleration of growth of the US economy is a key reason why the world economy is expected to grow by about $3 \%$, compared to $2.5 \%$ in 2014 . Japan, the third largest economy in the world, slipped into recession, and is expected to grow by a modest $0.8 \%$, compared to the significant $1.54 \%$ in 2013. India's economy is expected to grow by $6.4 \%$ and $6.6 \%$ in 2015, which is a significant increase compared to 5.6\% in 2014. (Chart 1) (MMF, 2015, www.imf.org). 


\section{Chart 1: The largest economies in the world}

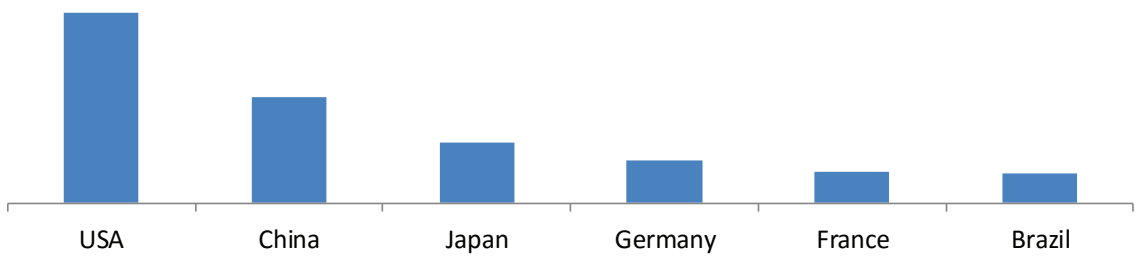

Source: MMF, (2015). www.imf.org

Increasing activity in developed economies, especially in the field of investments with a high import share, should accelerate world trade during the coming period and enable its recovery. However, it is estimated that world trade will probably not expand at the same pace as before. World trade (excluding Euro Zone) should increase by 5.7\% in 2015 and $5.9 \%$ in 2016. (Table 1). It is expected that the growth of import demand of the main trading partners Euro Zone would be slower than demand from the rest of the world, causing a rise in external demand of Euro Zone weaker than the growth of world trade (WTO, 2015, www.gatt.org).

Table 1: International environment (changes in \%) - June 2014

\begin{tabular}{|l|c|c|c|c|}
\hline & $\mathbf{2 0 1 3 .}$ & $\mathbf{2 0 1 4}$ & $\mathbf{2 0 1 5 .}$ & $\mathbf{2 0 1 6 .}$ \\
\hline $\begin{array}{l}\text { The real World GDP } \\
\text { (without Euro Zone) }\end{array}$ & 3,4 & 3,6 & 4,0 & 4,1 \\
\hline $\begin{array}{l}\text { The World } \\
\text { trade(without Euro } \\
\text { Zone) }\end{array}$ & 3,5 & 4,3 & 5,7 & 5,9 \\
\hline $\begin{array}{l}\text { External demand of } \\
\text { Euro Zone }\end{array}$ & 3,0 & 3,7 & 5,2 & 5,6 \\
\hline
\end{tabular}

Source: WTO, (2015). www.gatt.org

According to the figures of foreign trade in 2013, China is the first time surpassed the United States, according to IMF forecasts, China is expected in four years to become quite close to America in the GDP, calculated on the basis of purchasing power parity. In the next four years China's share of global GDP will be also almost equated with participation of the US in GDP. In 2013 China realized trade with the rest of the world in amount of 4.2 billion dollars, which is $7.6 \%$ higher than the value in 2012 . China's exports in 2013 amounted to 2.2 billion US dollars, $8 \%$ more than the previous year, while imports increased by $7.3 \%$ to approximately $\$ 2$ billion. For 11 months in 2013 , the United States, the largest economy recorded a foreign trade turnover of 3.5 billion dollars. In 2013, China has participated in world GDP in 15.4\% and America in $18.6 \%$. China's GDP in 2018 will be worth 20.7 billion dollars and US' 21.7 billion, based on 
this very important economic indicator, the difference between the two countries would significantly reduce. The rapid growth of China's GDP would allow China to realize share in global GDP in 2018 in amount of $17.9 \%$, comparing to US' 18.6\% GDP (MMF, 2015, www.imf.org)

In longer term perspective, assuming that there will not be a further tightening of tensions at the global level, gradual acceleration of growth in real GDP is anticipated during the next period. It is expected that the growth rate of world real GDP (excluding the Euro zone) would raise from $4.0 \%$ in 2015 and $4.1 \%$ in 2016. The growth of real GDP should accelerate in 2015 and 2016, provided that the differences in growth between countries should reduce (IMF, 2015, www.imf.org).

Speaking about the European economy, its recovery started in the second quarter of 2013 , but that growth is still unstable, while the economic dynamics in many members of Euro Zone remains weak. Despite the favorable financial conditions, economic recovery in 2015 will be slow, reflecting a gradual easing the consequences of the crisis with still high unemployment, high debt and low capacity utilization.

In 2014, the range of growth rates of the members of Euro Zone was very broad, from $-0.7 \%$ (Balkan countries with traditionally low economic growth) to $4.6 \%$ (Ireland, the most promising European economy). However, the difference in growth is likely to shrink over the next two years. In 2015 and 2016 all Member States should record positive growth (ECB, 2015, www.ecb.europa.eu).

Due to increased geopolitical risks and adverse global economic perspective, it is predicted that the EU and Euro Zone would have a fairly weak economic growth. It is expected that the growth of real GDP could be $1.5 \%$ in the EU and $1.1 \%$ in 2015 in the Euro Zone (ECB, 2015, www.ecb.europa.eu).

The tension between the EU and Russia certainly had some effects on Euro Zone's exports, while countries with relatively strong trade links with Russia were quite significantly affected. The European Union fears also from China. Chinese trade surplus with the EU hourly increase for \$20 million, and in 2015 will reach the sum of 170 billion Euros (227 billion dollars), while the deficit in EU trade with China is likely to be higher than the US' (which was in 2014, 232.5 billion US dollars) (ECB, 2015, www. ecb.europa.eu).

Exports within Euro Zone should grow somewhat more slowly than exports to countries outside the Euro Zone due to still fairly weak domestic demand in Euro Zone. Import from countries outside Euro Zone is expected to moderately grow in the next period. It is expected that net trade will contribute to a moderate growth of real GDP.

In 2016, increased domestic and foreign demand, as well as the further implementation of a very flexible monetary policy, related with the low cost of financing, should support further strengthening of economic growth.

\section{The impact of the economic disintegration to trade in Serbia}

International economic relations are characterized by strong regional processes of economic integration and economic cooperation between the countries. Very often, they 
are conditioned by the political relations in a particular geographic area or are a result of specific cultural, ethnic, geographic and similar characteristics. Nevertheless, regional cooperation and integration are becoming part of the general development trends of the modern world in the sense of realization of economic and other goals and interests of countries and regions.

Unlike other areas in Europe, which have made significant progress in the field of regional cooperation and economic integration, the Balkan region continues still represent disjointed and economically disintegrated area. The result of it is deepening gap between the European Union and the Balkan countries. However, the Balkan countries in recent years have affected by the processes that besides major political changes, include the construction of new economic relations, which should enable the resolution of a number of economic problems of the region.

Balkan countries, including Serbia, are located on the historic crossroads, conditioning whether the Balkan region would have a future. Events in recent years indicate that regional cooperation in the Balkans has good perspective. The way to overcome many political, social and economic problems inherent in the Balkan countries is in the expansion of regional cooperation and their tighter integration with the European Union.

In 2015, the Balkans, as well as Serbia, from the standpoint of the economic environment, implemented market reforms and European integration processes, still has not even nearly reached the level of successful countries (EBRD, 2015, www.ebrd.com).

The Serbian economic growth from 2001 was based less on reforms and more on a "consumer model", which was only possible due to large privatization revenues and significant borrowing abroad.

In the previous decade, the economic growth and development was carried out in an attempt to achieve growth in both private and public consumption and, on the other hand, through market reforms, privatization and the influx of foreign investments to create the institutional and material conditions for stable development. The second major problem was the unfavorable structure of creation and use of the growing GDP, which led to increasing exports imbalance due to growing trade and current account deficits.

The current model of economic growth and development of Serbia is not sustainable and must be changed fundamentally in order to avoid the fate of undeveloped and heavily indebted countries. The model which involves considerably faster growth of domestic demand than GDP growth due to the growing share of the current account deficit to GDP ratio is unsustainable. Given the over-drying privatization revenues and limited possibilities for further excessive borrowing abroad, Serbia has to turn to a new model of economic growth and development that is pro-investment and export-oriented (Government of Serbia, 2015, www.srbija.gov.rs).

In 2013, real GDP growth in Serbia was 2.6\%. The fall in GDP of Serbia in 2014 was $1.8 \%$. Observed by quarters, in 2014 real GDP fall compared to the same period last year was $0.2 \%$ in the first quarter, $1.2 \%$ in the second quarter, $3.8 \%$ in the third quarter and $1.8 \% \mathrm{t}$ in he fourth quarter. In the fourth quarter of 2014, the decline in GDP continued but in lower intensity than in the previous quarter. Gross domestic product in real terms decreased by $1.6 \%$ compared to the fourth quarter of 2013 (NBS, 2015, www.nbs.rs).

In December 2014 downward trend in exports was interrupted. Exported goods amounted to 957.1 million euro which is $6.5 \%$ more than in December 2013. The value 
of imported goods was 1.4 billion euro, representing a decline of $1 \%$. Foreign trade deficit of $13.7 \%$ was lower than in December 2013, while $67.6 \%$ of imports were covered by exports (RZS, 2015, www.stat.gov.rs).

Looking regionally, the biggest share in Serbian exports was in Vojvodina region $(33.3 \%)$, followed by Sumadija and Western Serbia $(31.6 \%)$, the Belgrade region $(21.3 \%)$, Southern and Eastern Serbia (13.4\%), and about $0.3 \%$ of exports was unclassified by territories. The biggest share in imports had Belgrade region (42.6\%), followed by Vojvodina region (29.4\%) (RZS, 2015, www.stat.gov.rs).

In 2014, exports of goods amounted to 11.2 billion euro and 15.5 billion euro, which is an increase of $1.4 \%$ and $0.4 \%$ compared to 2013. (Chart 2). Trade deficit during the same period amounted to 4.4 billion euro and decreased by $2.3 \%$ compared to the same period last year. The biggest share in exports related to road vehicles (13.8\%). A significant share in exports was related to electrical machinery and appliances, cereals, vegetables and fruits, metal products and clothing, which together with road vehicles makes $40.3 \%$ of total exports. Import of road vehicles, petroleum and petroleum products, electrical machinery and gas was 27\% of total imports in 2014 (RZS, 2015, www.stat.gov.rs).

\section{Chart 2: Structure of exports and imports in 2013 and 2014 in million of EUR}

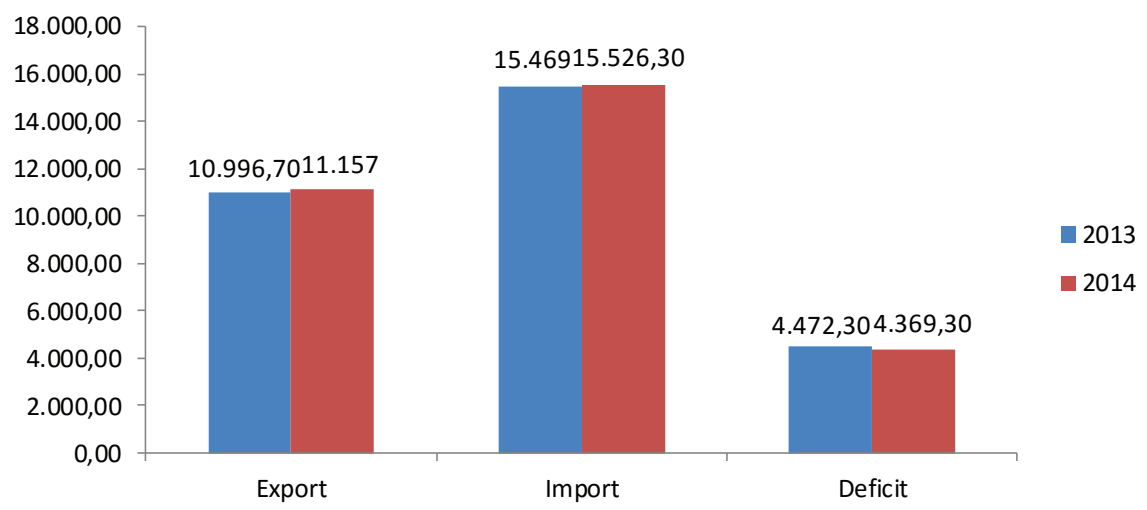

Source: Republic Statistical Office of Serbia, SORS, (2015).www.stat.gov.rs

The positive balance of foreign trade (1331.1 million Euro) was realized by sectors: food and live animals, beverages and tobacco, and miscellaneous manufactured articles (furniture, clothing and footwear) (RZS, 2015, www.stat.gov.rs).

The largest trade partner in 2014 was EU, which accounted for $64.6 \%$ of total exports and $63.1 \%$ of total imports. Half of the total export in this period was focused on the market of five countries: Italy, Germany, Bosnia, Russia and Romania (Chart 3). Imports from Germany, Russian Federation, Italy, China and Hungary accounted for $46.8 \%$ of total imports (Chart 4). Trade with Bosnia and Herzegovina, Montenegro, Macedonia, Italy, Romania, and the United States recorded a surplus of 1.8 billion euro. 
Chart 3: Structure of exports by countries in 2014 (mil. EUR)

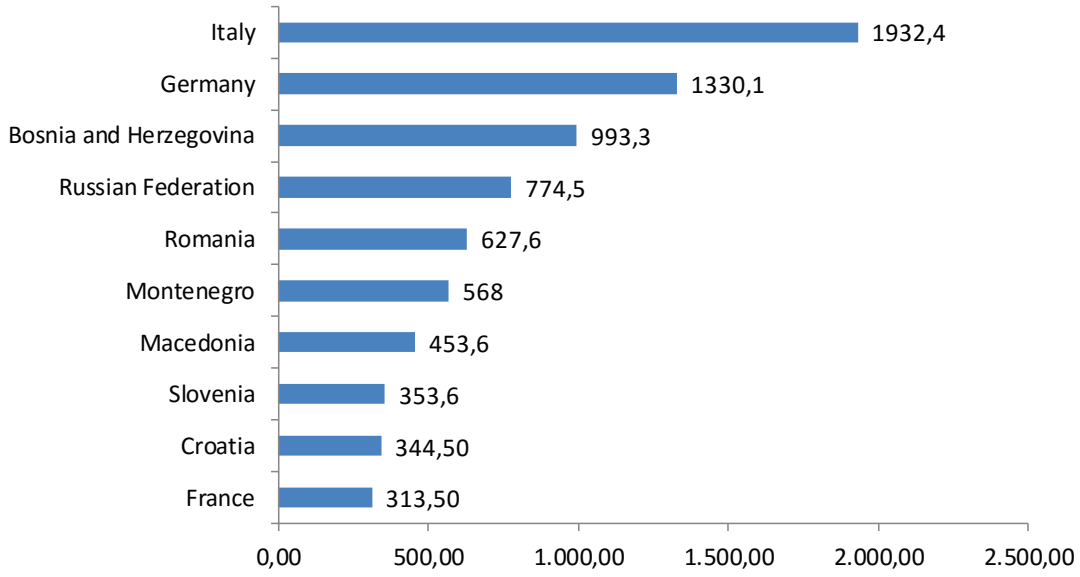

Source: Republic Statistical Office of Serbia, SORS, 2015. www.stat.gov.rs

Chart 4: Structure of imports by countries in 2014 (mil. EUR)

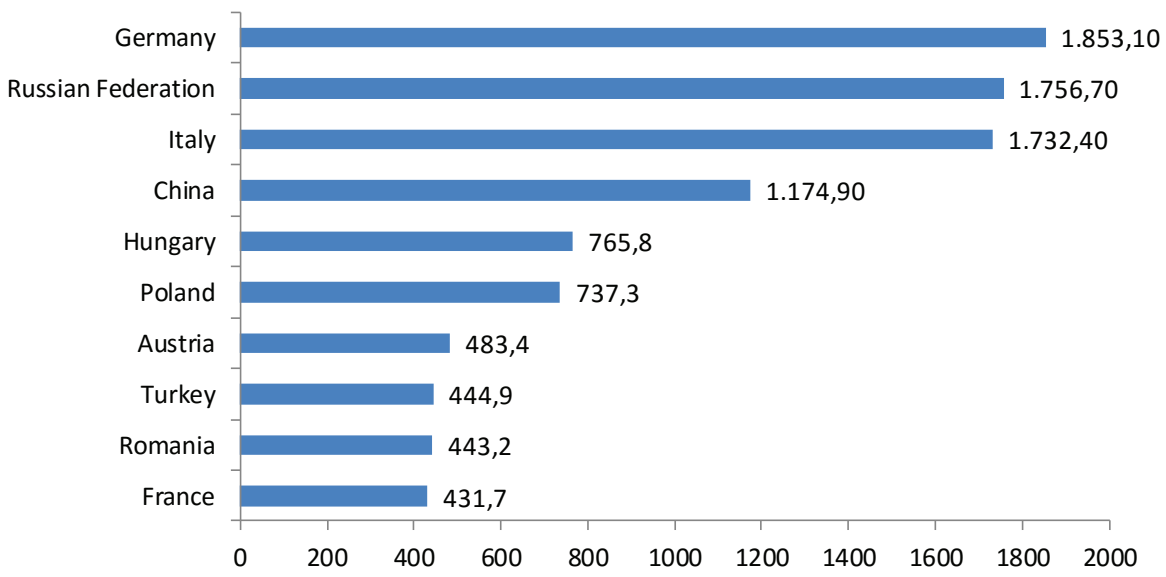

Source: Republic Statistical Office of Serbia, SORS, 2015. www.stat.gov.rs

Total external debt at end-November in 2014 amounted to 26.344 million euro, compared with the end of 2013 it was an increase of 580 million euro. The external debt of the public sector has increased by 776 million euro and amounted to 13.942 million euro, while private sector's external debt was reduced by 195 million euro and amounted 12.403 million euro. In the same period, the structure of the external debt of the private sector banks' debt was reduced by 649 million euro and amounted to 2,754 million euro, while corporate debt increased by 453 million euro to 9,647 million euro (NBS, 2015, www.nbs.rs). 
Prospective for recovery of the real sector in Serbia are uncertain. It is necessary to create a favorable environment for business and achieve economic stability (Vukovic, \& Pavicevic, 2015).

Incoming period requires a new model of economic growth and development, which requires a shift from consumerism to pro-investment and export-oriented economic growth. A shift is needed in the area of accelerating reforms and European integration and appropriate macroeconomic and structural policies.

\section{Conclusion}

The basic feature of the world economy last decade is the dynamic development of international trade. The share of national exports in total world exports is one of the most important indicators of economic expansion of the economy. Rampant globalization process of the world economy and liberalization of international trade led to numerous regional, both economic and political integration. Regional economic integration contributes to the development of trade between the countries in the region, and thus intensifies and develops their internal trade.

In the conditions of globalization that can increase global economic growth, but also could deepen the gap between rich and poor countries, and finally eliminate from the competition the least developed economies, it is essential to improving international trade relations. Removing obstacles to trade policy and the opening of the market to less developed countries, a stable trade policy lead to economic progress for all countries.

The concept of economic policy should consider several important changes in the environment. Incoming years, microeconomic and macroeconomic risks will be more pronounced, regulatory requirements at national and international level will be raised and the current fiscal relaxation of most countries in the world that has prevented the collapse in demand will take longer. Fighting the recession, the decline in exports, increased unemployment in the world, can encourage governments and central banks of some countries to depreciation of the national currency, which can lead to increased protectionism, trade wars and growing instability in international economic relations. Uncertainties and risks of impacts on economic developments are many and varied and can change diametrically planning projections of the global economy.

\section{References}

EBRD, (2015): www.ebrd.com,10.7.2015.

RZS, (2015): www.stat.gov.rs, 10.7.2015.

Vlada Republike Srbije, (2015): www.srbija.gov.rs,10.7.2015.

Vukmirica, V., (2000): Svetska trgovinska politika i tržišta, Beograd, Grmeč Privredni pregled

Vuković, A., Đoković, G., \& Rončević, D. (2013). Uloga ekonomike trgovine u međunarodnoj ekonomiji. Ekonomika, 59(2), 57-72.

Vuković, A., Pavićević, A., (2015): Siva ekonomija kao posledica poremećaja privredne strukture, Novi Sad, Kultura polisa, 12(27), 163-172. 
WTO, (2015): www.gatt.org, 25.6.2015.

Župljanin, S., (2010): Savremena trgovina - Strategije i politike trgovine u BiH, Banja Luka, NUBL, p. 119).

Krugman, P., Obstfeld, M., (2000): International Economics, Journal of international economics

Mankiw., (1997): Ten Principles of Economics, USA

Božić, M., (2006): Ekonomska politika, Pravni fakultet - Centar za publikacije, Niš

ECB, (2015): www.ecb.europa.eu, 1.7.2015.

Bjeliæ, P., (2003): Ekonomika meðunarodnih odnosa, Beograd

Eurostat, (2015): www.epp.eurostat.ec.europa.eu, 8.7.2015.

Guardian, (2014): www.theguardian.com, 25.6.2015.

Leković, V., (1999): Globalizacija svetske privrede - ključni faktori i nosioci, Ekonomiski horizonti, 1-2, 127-141.

Lovreta, S., (1999): Trgovinski menadžment, Beograd, Ekonomski fakultet

MMF, (2015): www.imf.org, 26.6.2015.

NBS, (2015): www.nbs.rs, 10.7.2015.

Radosavljević, Ž., (2006): Trgovinski menadžment, Beograd, Centar za edukaciju rukovodećih kadrova (CERK), p.47.) 
